\title{
HATS IN THE RING
}




\section{JUDAISM AND JEWISH LIFE}

Series Editor: Simcha Fishbane, Touro College, New York

\section{Editorial Board:}

Geoffrey Alderman (University of Buckingham, Buckingham)

Meir Bar-Ilan (Bar-Ilan University, Ramat Gan)

Herbert Basser (Queen's University, Kingston, Ontario)

Donatella Ester Di Cesare (Universita La Sapienza, Rome)

Roberta Rosenberg Farber (Yeshiva University, New York)

Andreas Nachama (Touro College, Berlin)

Ira Robinson (Concordia University, Montreal)

Nissan Rubin (Bar-Ilan University, Ramat Gan)

Susan Starr Sered (Suffolk University, Boston)

Reeva Spector Simon (Yeshiva University, New York) 


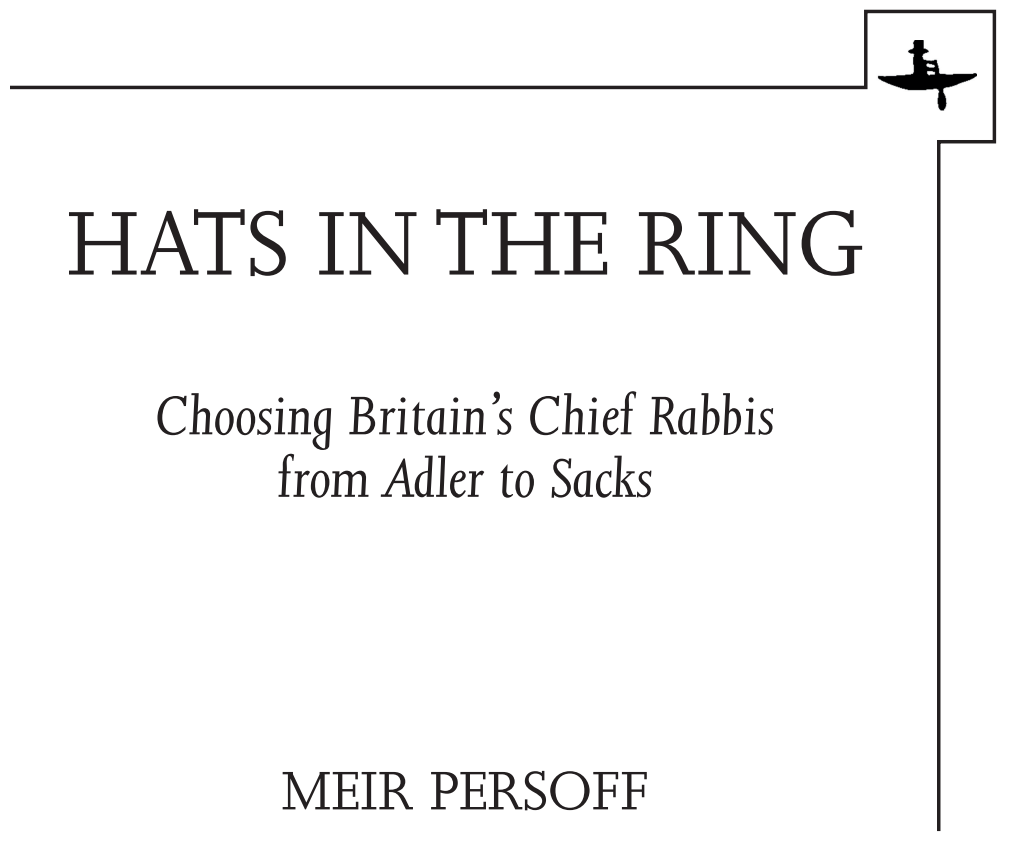

ACADEMIC STUDIES PRESS

Boston 2013 
First published in 2013 by Academic Studies Press

28 Montfern Avenue

Brighton, MA 02135

United States of America

press@academicstudiespress.com

www.academicstudiespress.com

Copyright (C) 2013 Meir Persoff

Meir Persoff has asserted his right under the Copyright, Designs and

Patents Act 1988 to be identified as the author of this work.

Library of Congress Cataloging-in-Publication Data:

Persoff, Meir.

Hats in the Ring: Choosing Britain's chief rabbis from Adler to Sacks / Meir Persoff.

pages $\mathrm{cm}$. - (Judaism and Jewish life)

Includes bibliographical references and index.

ISBN 978-1-61811-177-7 (cloth)

ISBN 978-1-61811-269-9 (paper)

ISBN 978-1-61811-199-9 (ebook)

1. British Chief Rabbinate-Selection and appointment-History.

2. Rabbis-Selection and appointment-England. I. Title.

BM292.P46 2013

296.6'7-dc23

2013000178

All rights reserved. No part of this publication may be reproduced, stored in or introduced into a retrieval system, or transmitted, in any form or by any means, electronic, mechanical, photocopying, recording, or otherwise without the prior written permission of the publisher of this book.

Book design by Adell Medovoy

Typeset in Joanna MT 11/13 
Dedicated to the

revered and blessed memory of

Emeritus Chief Rabbi Lord Jakobovits

and Lady Amélie Jakobovits 

'Rabbi Yitzchak said: "Do not appoint a leader before consulting the community."

Talmud, tractate Berachot 55a 
